\title{
Co-delivery of doxorubicin and recombinant plasmid pHSP70-Plk I-shRNA by bacterial magnetosomes for osteosarcoma therapy
}

This article was published in the following Dove Press journal:

International Journal of Nanomedicine

25 October 2016

Number of times this article has been viewed

\section{Li Cheng \\ Youqun Ke \\ Shuisheng Yu \\ Juehua Jing}

Department of Orthopaedics, The Second Affiliated Hospital of Anhui Medical University, Anhui Medical University, Hefei, Anhui, People's Republic of China
Correspondence: Juehua Jing Department of Orthopaedics, The Second Affiliated Hospital of Anhui Medical University, Anhui Medical University, 678 Fu Rong Road, Hefei, Anhui 23060I, People's Republic of China Tel +86055I 63869505

Fax +86 055I 63869400 Email aydtgzy@।63.com
Abstract: To explore a novel combination of chemotherapy, gene therapy, and thermotherapy for osteosarcoma, a targeted heat-sensitive co-delivery system based on bacterial magnetosomes (BMs) was developed. The optimal culture conditions of magnetotactic bacteria (MTB) AMB-1 and characterization of BMs were achieved. A recombinant eukaryotic plasmid heat shock protein 70-polo-like kinase 1-short hairpin RNA (pHSP70-Plk1-shRNA) under transcriptional control of a thermosensitive promoter (human HSP70 promoter) was constructed for gene therapy. Doxorubicin (DOX) and pHSP70-Plk1-shRNA were included in the targeted thermosensitive co-delivery system, and in vitro DOX release activity, targeted gene silencing efficiency and in vitro antitumor efficacy were investigated. The results showed that the optimal culture conditions of MTB AMB-1 are an oxygen concentration of $4.0 \%$, a pH value of $7.0,20 \mu \mathrm{mol} / \mathrm{L}$ of ferrous sulfate, $800 \mathrm{mg} / \mathrm{L}$ of sodium nitrate, and $200 \mathrm{mg} / \mathrm{L}$ of succinic acid. The temperature of BMs reached $43^{\circ} \mathrm{C}$ within 3 minutes and could be maintained for 30 minutes by adjusting the magnitude of the alternating magnetic field (AMF). The diameters of BMs, BM-DOX, BM-recombinant eukaryotic plasmid pHSP70-Plk1-shRNA (shPlk1), and BM-DOX-shPlk1 were 43.7 $\pm 4.6,79.2 \pm 5.4,88.9 \pm 7.8$, and $133.5 \pm 11.4 \mathrm{~nm}$, respectively. The zeta potentials of BMs, BM-DOX, BM-shPlk1, and BMDOX-shPlk1 were $-29.4 \pm 6.9,-9.5 \pm 5.6,-16.7 \pm 4.8$, and $-10.3 \pm 3.1 \mathrm{mV}$, respectively. Besides, the system exhibited good release behavior. DOX release rate from BM-DOX-shPlk1 was 54\% after incubation with phosphate-buffered saline at $43^{\circ} \mathrm{C}$ and $37 \%$ after incubation with $50 \%$ fetal bovine serum, which was significantly higher than that at $37^{\circ} \mathrm{C}(P<0.05)$. In addition, the expressions of Plk1 mRNA and protein were significantly suppressed in cells treated with BMDOX-shPlk1 following hyperthermia treatment under the influence of an AMF compared to other groups $(P<0.05)$. Furthermore, evaluation of the effect of in vitro antitumor revealed that BMDOX-shPlk1 following hyperthermia treatment under the influence of an AMF was significantly more effective than others in tumor inhibition. In conclusion, the new heat-sensitive co-delivery system represents a promising approach for the treatment of cancer.

Keywords: magnetotactic bacteria, heat-inducible gene expression, alternating magnetic field, chemotherapy, gene therapy, thermotherapy

\section{Introduction}

Gene-based therapies are potential approaches to the treatment of cancer. However, the therapeutic efficacy remains challenging. Delivery of therapeutic genes to an identified tissue and controlled gene expression are extremely important. ${ }^{1-3}$

Magnetic hyperthermia is a highly recommended technique that is used to treat cancers in which magnetic nanoparticles are administered to tumors and heated under the influence of an alternating magnetic field (AMF). ${ }^{4,5}$ Recently, it has been revealed 
that there are certain technical problems with chemically synthesized magnetic nanoparticles, such as poor dispersion, propensity of congregation and low drug loading. ${ }^{6,7}$ Bacterial magnetosomes (BMs), extracted from magnetotactic bacteria (MTB), are considered to be of increasing interest as drug carriers mainly due to their biocompatibility and low toxicity. It has been shown that BMs coupled with doxorubicin (DOX) display a potential antitumor property. ${ }^{8-13}$ However, bacterial cultivation is still a problem. The efficiency of BMs used in the magnetic hyperthermia treatment of tumors needs more experimental data to be understood.

Previous studies showed that expression of genes under the control of heat shock protein 70 (HSP70) promoter can be elevated by heat stress $\left(39^{\circ} \mathrm{C}-43^{\circ} \mathrm{C}\right)$. The HSP70 promoter system has been used as an inducible gene expression system to control therapeutic gene expression which achieves spatial and temporal targeting of therapy. ${ }^{14-17}$ Polo-like kinase 1 (Plk1) is an essential regulator of mitosis and an emerging target for cancer therapy. Aberrant expression of Plk1 has been shown to promote the growth of lung cancer, gastric cancer, and osteosarcoma. Suppressing the expression of Plk1 by plasmid encoding specific interfering short hairpin RNA (shRNA) against Plk1 can promote apoptosis and inhibit proliferation of tumor cells. ${ }^{18-21}$

In this study, a novel thermosensitive tumor-targeted therapy system was developed on the basis of BMs which were under the influence of an AMF. In addition, DOX and recombinant plasmid HSP70 (pHSP70)-Plk1-shRNA were loaded into the system (BM-DOX-recombinant eukaryotic plasmid pHSP70-Plk1-shRNA [shPlk1]) for the combination of chemotherapy, gene therapy, and magnetic thermotherapy. Their antitumor effect was evaluated against osteosarcoma, and it was demonstrated that the therapy system offered a new strategy for the treatment of cancer.

\section{Materials and methods \\ Materials}

MTB AMB-1 was a generous gift from Dr Weidong Pan (Beijing Key Laboratory of Bioelectromagnetics, Institute of Electrical Engineering, Chinese Academy of Sciences, People's Republic of China). The Chinese Academy of Sciences Institutional Review Board approved the use of human cell lines for this study. Osteosarcoma U2-OS cells were obtained from the Cancer Institute of Chinese Academy of Medical Sciences (Beijing, People's Republic of China). Recombinant plasmid pHSP70-Plk1-shRNA was provided by GenePharma (Shanghai, People's Republic of China). DOX was purchased from Junning Technology Company (Shenzhen, People's
Republic of China). Anti-Plk1 antibody and anti-GAPDH antibody were supplied from Abcom (Cambridge, MA, USA). Polyethylenimine (PEI), fetal bovine serum (FBS), cell culture media, restriction endonucleases like HindIII and BamHI, and T4 DNA ligase were supplied by Invitrogen (Carlsbad, CA, USA). All cells were incubated at $37^{\circ} \mathrm{C}$ in humidified air with $5 \% \mathrm{CO}_{2}$. The other chemicals were purchased from Sigma (St Louis, MO, USA).

\section{Culture of MTB}

MTB AMB-1 was maintained in the growth medium which was autoclaved at $121^{\circ} \mathrm{C}$ for 20 minutes (min). The $\mathrm{pH}$ (7.0 \pm 0.1$)$, oxygen concentration $(0.8 \% \pm 0.2 \%)$, temperature $\left(28^{\circ} \mathrm{C} \pm 1^{\circ} \mathrm{C}\right)$, and agitation speed $(120 \pm 10 \mathrm{rpm})$ were kept constant and were monitored continuously during the study. Cells were cultured in a $250 \mathrm{~mL}$ serum bottle. Optimal culture condition was confirmed by adjusting the types and amounts of iron sources, nitrogen sources, and carbon sources. The growth of MTB AMB-1 was evaluated using optical density (OD) at $600 \mathrm{~nm}$ which was measured by an ultraviolet-visible (UV-vis) spectrophotometer.

\section{Isolation of BMs}

AMB-1 cells were collected by centrifugation $\left(4^{\circ} \mathrm{C}, 11,000 \mathrm{rpm}\right.$, $8 \mathrm{~min}$ ), suspended in $0.1 \mathrm{M}$ phosphate-buffered saline (PBS; $\mathrm{pH} 7.4$ ) and disrupted by an ultrasonic cell crusher $(300 \mathrm{~W}$, for $4 \mathrm{~s}$ with an interval of $8 \mathrm{~s}$, and repeated 80 times). BMs were absorbed by a magnet bound to the bottom of the beaker with cell debris removed. The BM sediments were collected after being resuspended in 0.1 M PBS ( $\mathrm{pH} 7.4)$ and ultrasonically cleaned $(45 \mathrm{~W}$, for $4 \mathrm{~s}$ with an interval of $8 \mathrm{~s}$, and repeated 40 times). All the processes were repeated 15 times. The purified BMs were sterilized by $\mathrm{Co}_{60}$ irradiation ( $15 \mathrm{kGy}$ ) and resuspended in 0.1 M PBS ( $\mathrm{pH} 7.4)$ (concentration of BMs added to $\mathrm{PBS}=500 \mu \mathrm{g} / \mathrm{mL}$ ).

\section{Construction of the recombinant plasmid pHSP70-PIkI-shRNA}

The construction was based on pEGFP-C1 (GenBank accession number U55763) vector which contains a GFP gene as a marker and a neomycin resistance gene. First, the CMV promoter in pEGFP-C1 vector was replaced by the promoter of the human HSP70 gene to construct a new vector (pHSP70-GFP). Then, the shRNA against Plk1 was designed on the basis of the human Plk1 gene mRNA sequence (NM_005030.3) in the GenBank database and subcloned into the pHSP70-GFP vector (pHSP70-Plk1-shRNA) (Figure 1). The multiple cloning site of pHSP70-GFP vector and the 


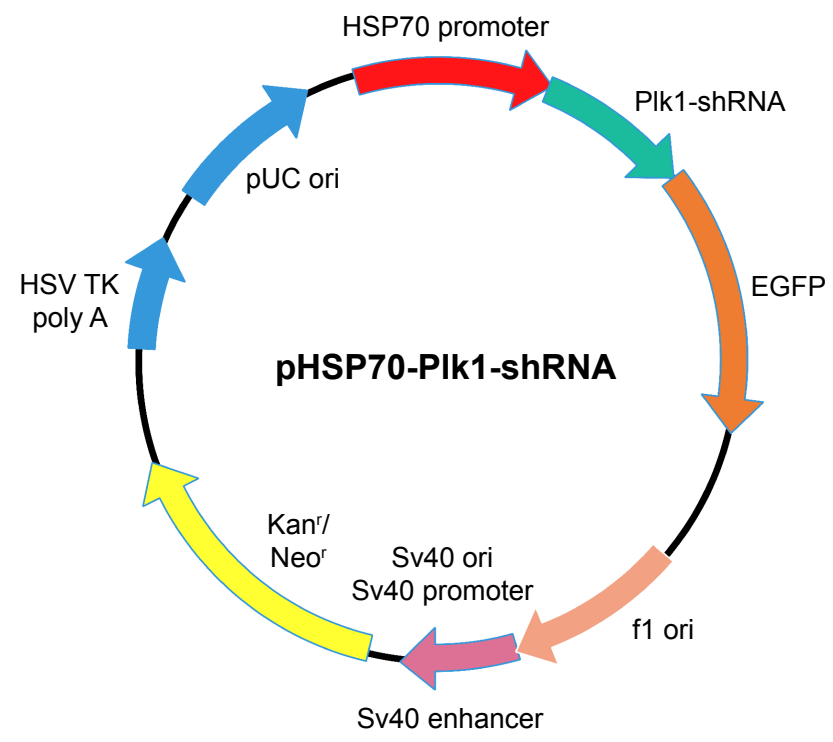

Figure I Schematic representation for the construction of the recombinant plasmid pHSP70-PlkI-shRNA.

Abbreviations: EGFP, enhanced green fluorescent protein; HSP70, heat shock protein 70; pHSP70, heat shock protein 70 promoter; Plk I-shRNA, polo-like kinase Ishort hairpin RNA; fl, bacteriophage $\mathrm{fl}$; ori, origin; Kanr, kanamycin resistant; Neor, neomycin resistant; Sv40, simian virus 40; HSV TK poly A, herpes simplex virus thymidine kinase polyadenylic acid.

amplified polymerase chain reaction (PCR) product of shRNA against Plk1 were simultaneously digested using HindIII and BamHI enzymes before the cut vector and PCR fragment were ligated by T4 DNA ligase. The ligated product was transformed into DH5 $\alpha$ cells overnight at $37^{\circ} \mathrm{C}$. The positive clones were collected and subcultured for 14 hours (h) before the recombinant plasmid was extracted and verified by the digestion with HindIII and BamHI restriction enzymes. Moreover, the authenticity of the recombinant plasmid pHSP70-Plk1-shRNA was confirmed by sequencing.

\section{Preparation of the BM-delivered DOX and pHSP70-PlkI-shRNA system}

The required amount of DOX solution $(1 \mathrm{mg} / \mathrm{mL}$, dissolved in distilled water) was added in the BM suspension $(200 \mu \mathrm{g} / \mathrm{mL})$ and was ultrasonically cleaned for $10 \mathrm{~min}$ to distribute the BMs uniformly. Then, the complex of PEI and pHSP70Plk1-shRNA vector was prepared in distilled water and ultrasonically washed for $5 \mathrm{~min}$. Finally, the BMs/DOX complex was added, and the mixture was cleaned ultrasonically until DOX and BMs were well-distributed. The BM-delivered DOX and pHSP70-Plk1-shRNA system (BM-DOX-shPlk1) were formed after incubation of the mixed solution at $37^{\circ} \mathrm{C}$ for $6 \mathrm{~h}$ (the ratio of BMs to pHSP70-Plk1-shRNA was 50:1 and the ratio of BMs to DOX was 5:4).

\section{In vitro cell transfection}

U2-OS cells were seeded in $60 \mathrm{~mm}$ dishes at a density of $5 \times 10^{5}$ cells/well. After incubation for $16 \mathrm{~h}$, the cells were washed twice with PBS and then $20 \mu \mathrm{L}$ of complexes was added into each well and incubated for $4 \mathrm{~h}$. Next, the medium was replaced with fresh medium containing serum, and the cells were incubated for $48 \mathrm{~h}$ prior to in vitro antitumor effect evaluation.

\section{Determination of magnetic field strength that can heat U2-OS cells incubated in the presence of $\mathrm{BMs}$}

After U2-OS cells were cultured on Petri dishes for $24 \mathrm{~h}$, BMs $(200 \mu \mathrm{g} / \mathrm{mL})$ were added and exposed to an AMF of frequency $54 \mathrm{kHz}$ and strength $21 \mathrm{mT}$ for $30 \mathrm{~min}$. The temperature of the cell suspension was measured using a thermocouple microprobe (Physitemp, Clifton, NJ, USA).

\section{DOX release assays}

DOX $(20 \mu \mathrm{L})$-loaded BMs were suspended in $1.5 \mathrm{~mL}$ PBS and PBS with 50\% FBS that simulate the in vivo environment separately in Eppendorf tubes. The samples were heated in a water bath at $37^{\circ} \mathrm{C}$ and $43^{\circ} \mathrm{C}$ for $1.5 \mathrm{~h}$, respectively. The DOX content in the supernate of each tube was evaluated in a fluorimeter using $590 \mathrm{~nm}$ emission and $485 \mathrm{~nm}$ excitation. The samples were incubated in $1.5 \mathrm{~mL}$ PBS with $1 \%$ Triton X-100 for $1 \mathrm{~min}$ for $100 \%$ release. The DOX release percentages were calculated according to the following formula: DOX release $(\%)=$ $\left(\mathrm{F}_{\mathrm{s}}-\mathrm{F}_{0}\right) /\left(\mathrm{F}_{100}-\mathrm{F}_{0}\right) \times 100 \%$, where $\mathrm{F}_{\mathrm{s}}$ was the fluorescence of samples after heating, $\mathrm{F}_{0}$ was the fluorescence of samples before heating, and $\mathrm{F}_{100}$ was the fluorescence of samples treated with Triton X-100.

\section{Real-time quantitative PCR}

After U2-OS cells were treated with different complexes $(20 \mu \mathrm{L})$ for $48 \mathrm{~h}$, total RNA was extracted from U2-OS cells using Trizol reagent following the manufacturer's instruction. Real-time quantitative PCR was performed by the Applied Biosystems high-capacity cDNA reverse transcription and SYBR green kits as described. Primers for Plk1 were as follows: upstream, 5'-TGACTCAACACGCCTCATCC-3'; and downstream, 5'-GCTCGCTCATGTAATTGCGG-3'. Plk1 mRNA level was normalized to that of GAPDH. GAPDH sense-strand was 5'-ACAGAACCCTGTGGGAGAAC-3' and GAPDH antisense-strand was 5'-GCGTTGCTCT CCTGTTCATA-3'. 


\section{Western blotting}

After U2-OS cells were treated with different complexes $(20 \mu \mathrm{L})$ for $48 \mathrm{~h}$, total protein was extracted from U2-OS cells using radioimmunoprecipitation assay (RIPA) lysis buffer following the manufacturer's instruction. Sixty micrograms of protein was separated by $10 \%$ sodium dodecyl sulfate polyacrylamide gel electrophoresis and transferred to polyvinylidene difluoride membranes. After blocking with $5 \%$ bovine serum albumin (BSA) solution for $1 \mathrm{~h}$ at room temperature, the membranes were incubated with primary antibodies overnight at $4{ }^{\circ} \mathrm{C}$ in Tris-buffered saline containing $0.05 \%$ Tween 20 and $5 \%$ BSA. The membranes were then incubated with corresponding secondary antibodies conjugated to horseradish peroxidase for $2 \mathrm{~h}$ at room temperature. The protein bands were visualized by ECL kit and analyzed by scanning densitometry.

\section{MTT assays}

U2-OS cells were treated with different complexes $(20 \mu \mathrm{L})$ at $37^{\circ} \mathrm{C}$ for $24,48,72$ and $96 \mathrm{~h}$ in 96 -well plates. Subsequently, $20 \mu \mathrm{L}$ of MTT was added to each well, and the cells were incubated at $37^{\circ} \mathrm{C}$ for $4 \mathrm{~h}$. Then $100 \mu \mathrm{L}$ of dimethylsulfoxide

\section{A}

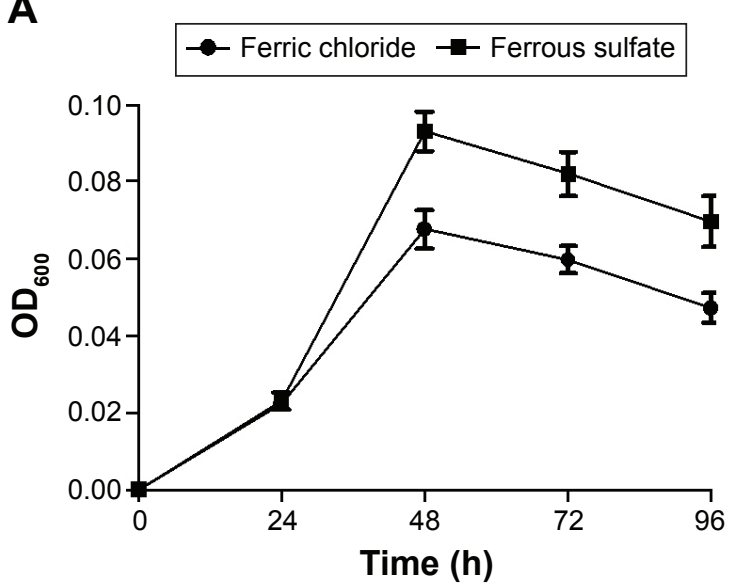

C

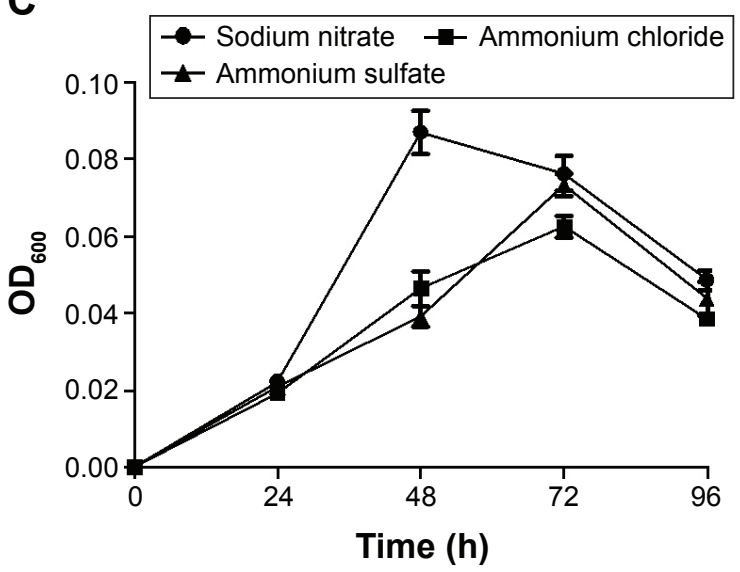

was added, and the OD at $490 \mathrm{~nm}$ was measured in a microplate reader. Cell proliferation was calculated according to the following formula: cell proliferation $(\%)=$ $\left(\mathrm{OD}_{\text {treat }}-\mathrm{OD}_{\text {blank }}\right) /\left(\mathrm{OD}_{\text {control }}-\mathrm{OD}_{\text {blank }}\right) \times 100 \%$.

\section{Flow cytometry assays}

Apoptosis was measured by the Annexin V-fluorescein isothiocyanate (FITC) Apoptosis Detection Kit (Invitrogen). U2-OS cells were treated with different complexes $(20 \mu \mathrm{L})$ at $37^{\circ} \mathrm{C}$ for $24 \mathrm{~h}$ in 12 -well plates. After the cells were harvested, washed twice with PBS, and suspended in $450 \mu \mathrm{L}$ binding buffer, Annexin V-FITC was added at room temperature. The cells were stained for $15 \mathrm{~min}$ without light and then were resuspended in $450 \mu \mathrm{L}$ binding buffer. Next the cells were stained with propidium iodide (PI) without light. Cell apoptosis was analyzed on a flow cytometer.

\section{Results}

\section{Culture conditions of MTB}

Figure 2 shows the growth of MTB AMB-1 under different conditions by regulating the types and amounts of iron
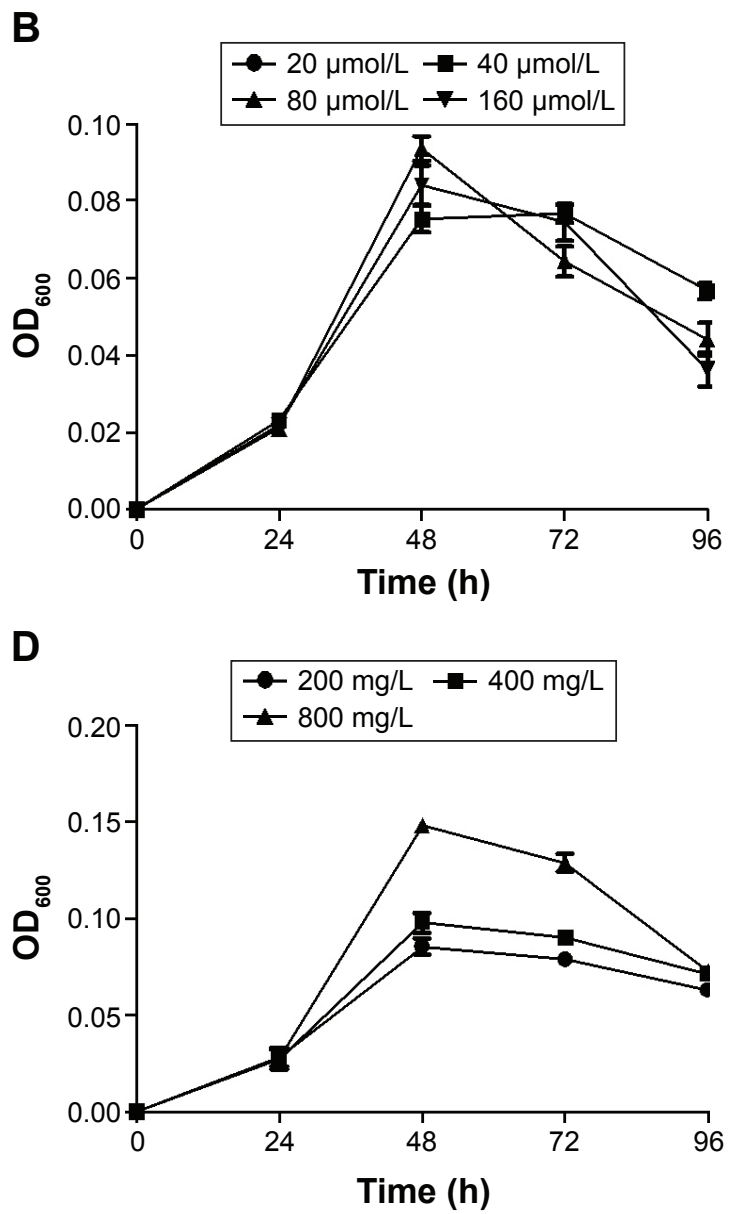

Figure 2 (Continued) 
E

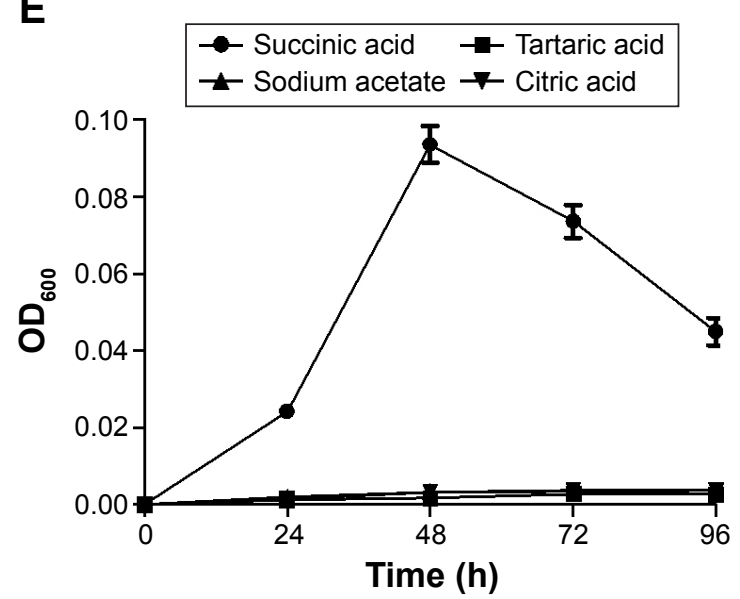

$\mathbf{F}$

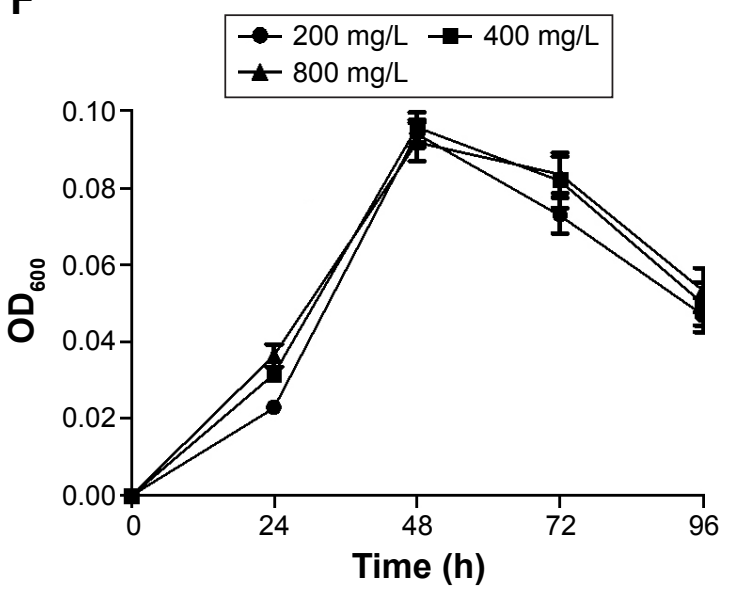

Figure 2 Growth curves of MTB AMB-I in various culture media.

Notes: Growth curves with (A) different iron sources (20 $\mu \mathrm{mol} / \mathrm{L})$; (B) when the concentration of ferrous sulfate ranged from 20 to I60 $\mu \mathrm{mol} / \mathrm{L}$; (C) different nitrogen sources ( $200 \mathrm{mg} / \mathrm{L})$; (D) when the concentration of sodium nitrate ranged from 200 to $800 \mathrm{mg} / \mathrm{L}$; (E) different carbon sources (200 mg/L); (F) when the concentration of succinic acid ranged from 200 to $800 \mathrm{mg} / \mathrm{L}$.

Abbreviations: MTB, magnetotactic bacteria; $\mathrm{OD}_{600}$, optical density at $600 \mathrm{~nm}$; h, hours.

sources, nitrogen sources, and carbon sources. As iron sources, ferrous sulfate enhanced the yield of MTB AMB-1 compared to ferric chloride (Figure 2A). When the concentration of ferrous sulfate ranged from 20 to $160 \mu \mathrm{mol} / \mathrm{L}$, no obvious changes in the yield were observed (Figure 2B). As nitrogen sources, sodium nitrate increased the yield of MTB AMB-1 compared to ammonium chloride and ammonium sulfate (Figure 2C). MTB AMB-1 production was gradually enhanced with increasing amounts of sodium nitrate ranging from 200 to $800 \mathrm{mg} / \mathrm{L}$ (Figure 2D). As carbon sources, succinic acid enhanced the yield compared to tartaric acid, sodium acetate, and citric acid (Figure 2E). However, MTB AMB-1 production remained constant with increasing amounts of succinic acid ranging from 200 to $800 \mathrm{mg} / \mathrm{L}$ (Figure 2F). These results showed that the optimal culture conditions of MTB AMB-1 are an oxygen concentration of $4.0 \%$, a $\mathrm{pH}$ value of $7.0,20 \mu \mathrm{mol} / \mathrm{L}$ of ferrous sulfate, $800 \mathrm{mg} / \mathrm{L}$ of sodium nitrate, and $200 \mathrm{mg} / \mathrm{L}$ of succinic acid.

\section{BM-induced hyperthermia}

Figure 3 shows the temperature of U2-OS cells irradiated with AMF. The temperature reached $43^{\circ} \mathrm{C}$ within 3 min and could be maintained for $30 \mathrm{~min}$. It revealed that the magnetic field strength that can heat U2-OS cells incubated in the presence of $\mathrm{BMs}$ to $43^{\circ} \mathrm{C}$ is $21 \mathrm{mT}$.

\section{Characterization of BM-DOX-shPIkI}

Electron microscopic image revealed typical whole MTB AMB-1 containing several chains of magnetosomes (Figure 4A). The magnetosomes were isolated from AMB-1 cells (Figure 4B) and were purified using ultrasonic cleaning
(Figure 4C). Atomic force microscopy showed that the diameter of BM-DOX was $79.2 \pm 5.4 \mathrm{~nm}$, which was larger than that of BMs $(43.7 \pm 4.6 \mathrm{~nm})$. Moreover, the diameter of BM-shPlk1 was $88.9 \pm 7.8 \mathrm{~nm}$, while that of BM-DOXshPlk1 increased to $133.5 \pm 11.4 \mathrm{~nm}$ as the encapsulation of DOX. The zeta potentials of BMs, BM-DOX, BM-shPlk1, and BM-DOX-shPlk1 were $-29.4 \pm 6.9,-9.5 \pm 5.6,-16.7 \pm 4.8$, and $-10.3 \pm 3.1 \mathrm{mV}$, respectively (Table 1 ).

\section{In vitro DOX release from the BM-DOX-shPlk I}

Figure 5 shows that the DOX release rates from BM-DOX and BM-DOX-shPlk1 were only $23.4 \%$ and $25.4 \%$ after incubation with $\mathrm{PBS}$ at $37^{\circ} \mathrm{C}$ and decreased to $16.1 \%$ and $15.0 \%$ after incubation with 50\% FBS, respectively. Moreover,

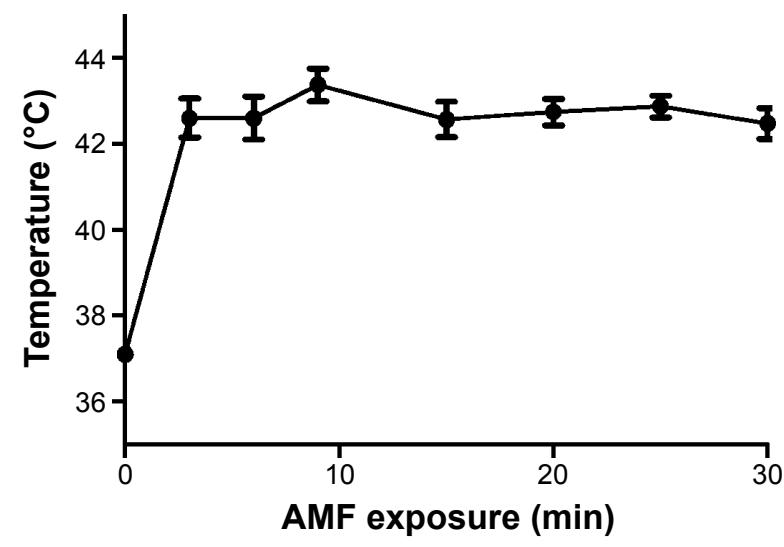

Figure $3 \mathrm{BM}$-induced hyperthermia in vitro.

Notes: U2-OS cells treated with BMs exposed to an AMF for 30 minutes (min). The temperature of the cells were maintained at $43^{\circ} \mathrm{C}$ after $3 \mathrm{~min}$ and measured using a thermocouple microprobe.

Abbreviations: AMF, alternating magnetic field; BM, bacterial magnetosome. 

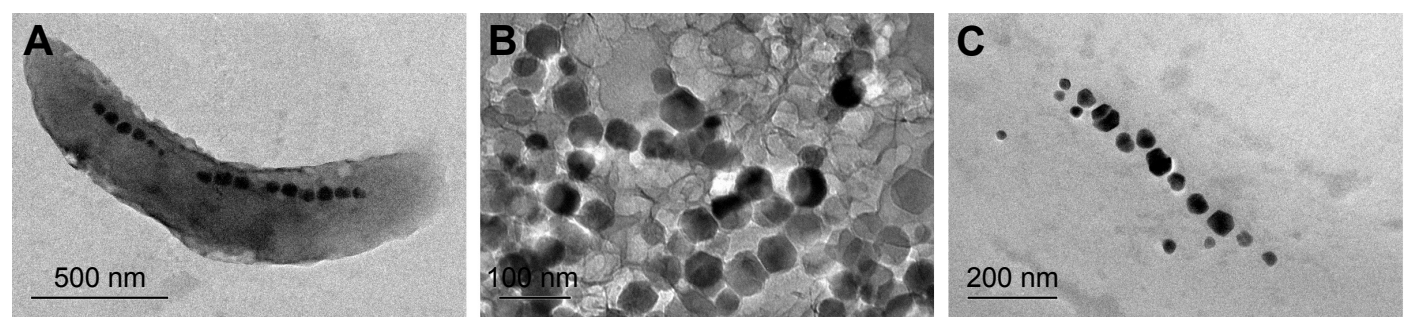

Figure 4 Transmission electron microscopy images of MTB AMB-I and BMs. Notes: Images of $(\mathbf{A})$ a single MTB AMB- I; (B) purified BMs; and (C) unpurified BMs. Abbreviations: BM, bacterial magnetosome; MTB, magnetotactic bacteria.

DOX release rates from BM-DOX and BM-DOX-shPlk1 were $49.7 \%$ and $54.0 \%$ after incubation with $\mathrm{PBS}$ at $43^{\circ} \mathrm{C}$ and decreased to $37.1 \%$ and $37.0 \%$ after incubation with $50 \%$ FBS, respectively, which was significantly higher than that at $37^{\circ} \mathrm{C}(P<0.05)$. The results indicate that the incorporation of plasmid had no significant effect on the stability of BMs $(P>0.05)$ and that BM-DOX-shPlk1 had desirable thermosensitivity and could be used for hyperthermia-triggered control release of DOX.

\section{PlkI expression driven by the HSP70 promoter was significantly induced by hyperthermia}

To determine whether the delivered BM-DOX-shPlk1 could mediate silencing of Plk1 expression in U2-OS cells, the expression of Plk1 1 day after treatment was evaluated by real-time quantitative PCR and Western blot. As shown in Figure 6, both Plk1 mRNA and protein levels decreased in cells treated with BM-DOX-shPlk1 compared to the cells treated with BM-DOX $(P<0.05)$. Furthermore, the expressions of Plk1 mRNA and protein were significantly suppressed in cells treated with BM-DOX-shPlk1 following hyperthermia treatment under the influence of an AMF compared to nonheated cells $(P<0.05)$. As shown in Figure 3 , the temperature of cells was maintained at $37^{\circ} \mathrm{C}$ or $43^{\circ} \mathrm{C}$ by controlling the magnitude of the AMF. These results suggested that Plk1 shRNA expression driven by the HSP70 promoter could be significantly induced by hyperthermia.

Table I Particle size and zeta potential of different groups

\begin{tabular}{lll}
\hline Group & $\begin{array}{l}\text { Particle } \\
\text { size }(\mathbf{n m})\end{array}$ & $\begin{array}{l}\text { Zeta } \\
\text { potential }(\mathbf{m V})\end{array}$ \\
\hline BMs & $43.7 \pm 4.6$ & $-29.4 \pm 6.9$ \\
BM-DOX & $79.2 \pm 5.4$ & $-9.5 \pm 5.6$ \\
BM-shPlkI & $88.9 \pm 7.8$ & $-16.7 \pm 4.8$ \\
BM-DOX-shPlkI & $133.5 \pm I \mid .4$ & $-10.3 \pm 3.1$ \\
\hline
\end{tabular}

Abbreviations: BM, bacterial magnetosome; DOX, doxorubicin; PlkI, polo-like kinase I; shPIkI, recombinant eukaryotic plasmid pHSP70-PIkI-shRNA.

\section{Therapeutic effect of BM-DOX-shPlkI} Inhibition of U2-OS cell proliferation tested by MTT To determine the influence on U2-OS cell proliferation after different treatments, the MTT cell viability assay was performed. As shown in Figure 7, the growth of U2-OS cells was inhibited in all groups. However, the cell proliferation inhibition rate of the combined group with BM-DOX-shPlk1 and AMF treatment was significantly lower than that of the BM-DOX-shPlk1 group and BM-DOX group $(P<0.05)$.

\section{Flow cytometric analysis of apoptosis}

Flow cytometry using Annexin V-Fluorescence and PI-stained U2-OS cells was performed to quantitatively determine the percentage of apoptotic cells at $48 \mathrm{~h}$ after different treatments. As shown in Figure 8, apoptosis rate was 40.7\% in cells treated with BM-DOX and increased to $57.9 \%$ in cells treated with BM-DOX-shPlk1. By contrast, the apoptosis rate was $79.3 \%$ in the combined group with BM-DOX-shPlk1 and AMF treatment, which was obviously greater than other groups $(P<0.05)$. In a nutshell, the above data indicated that the combined treatment of chemotherapy, gene therapy, and magnetic thermotherapy, using BMs as the link, could provide a good synergetic antitumor effect in vitro.

\section{Discussion}

Osteosarcoma is the most common malignant bone tumor of childhood. Surgery in combination with routine chemotherapy is the standard treatment. However, the 5-year survival rate of osteosarcoma patients is only $60 \%-70 \%{ }^{22,23}$ Therefore, novel approaches need to be rationally developed to treat patients diagnosed with osteosarcoma. Although recent progress in identifying various molecular targets has revealed that genebased target therapy is a novel approach, unsatisfactory therapeutic effects remain due to the uncontrollable gene expression level and effective regions. ${ }^{24}$ Building a new delivery system is the key to overcome the aforementioned problems.

Hyperthermia is a promising tool for the treatment of many types of tumor as the enhancement of antitumor effect. 

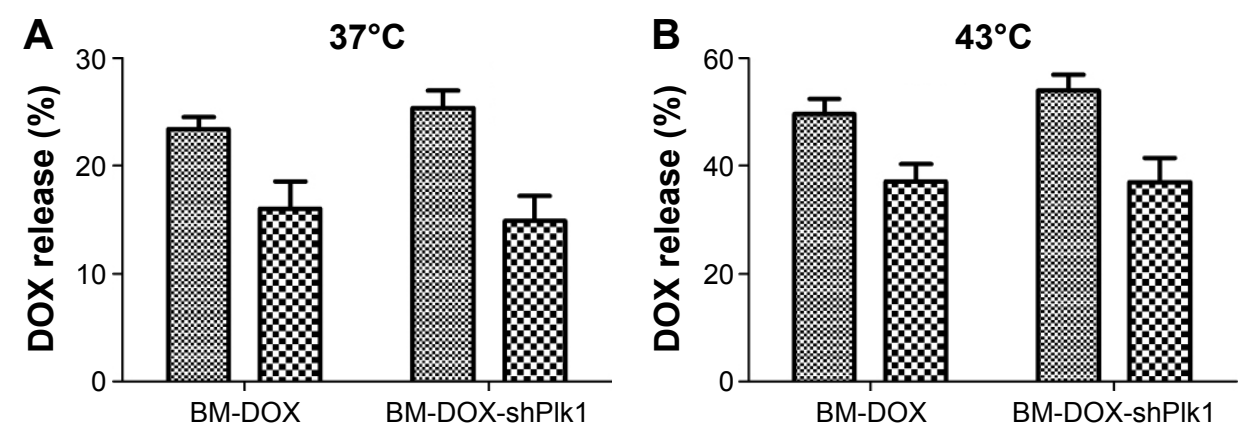

Figure 5 Results of DOX release test in vitro.

Notes: The release rates of DOX from (A) BM-DOX and BM-DOX-shPlkI at $37^{\circ} \mathrm{C}$ after incubation in PBS or 50\% FBS; (B) BM-DOX and BM-DOX-shPlkI at $43^{\circ} \mathrm{C}$ after incubation in PBS or $50 \%$ FBS. Each value is represented as mean \pm SD $(n=6)$.

Abbreviations: BM, bacterial magnetosome; DOX, doxorubicin; FBS, fetal bovine serum; PBS, phosphate-buffered saline; PlkI, polo-like kinase I; shPlkI, recombinant eukaryotic plasmid pHSP70-PIkI-shRNA; SD, standard deviation.

Research studies have shown that hyperthermia is produced by magnetic nanoparticles such as BMs and that they generate heat under an AMF. ${ }^{25-27}$ BMs are membrane-bound nanocrystals with a magnetic iron sulfide or iron oxide core and extracted from MTB. They were considered excellent candidates for magnetic targeting drug carriers because of their unique features, such as nanoscale size $(40-120 \mathrm{~nm})$, high dispersal quality, and superparamagnetism. ${ }^{28}$ Furthermore, previous studies showed that BMs are novel nanoparticles with excellent biocompatibility as the stable lipid membrane. They have been used as carriers for chemical drugs and recombinant plasmids. ${ }^{29,30}$ Until now, studies of MTB have
A

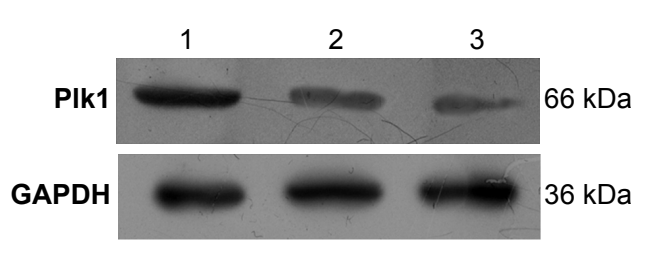

B

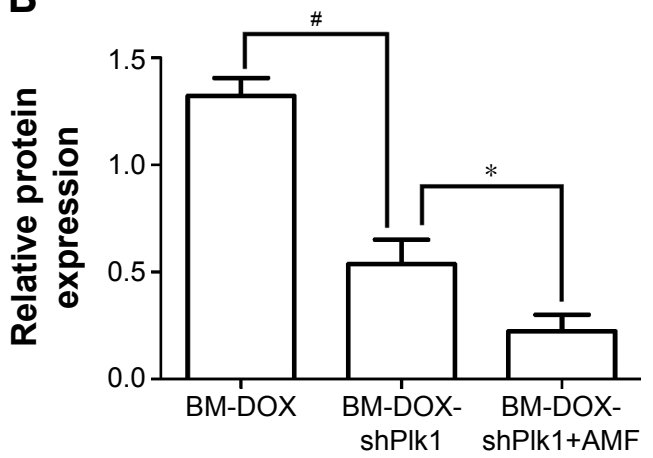

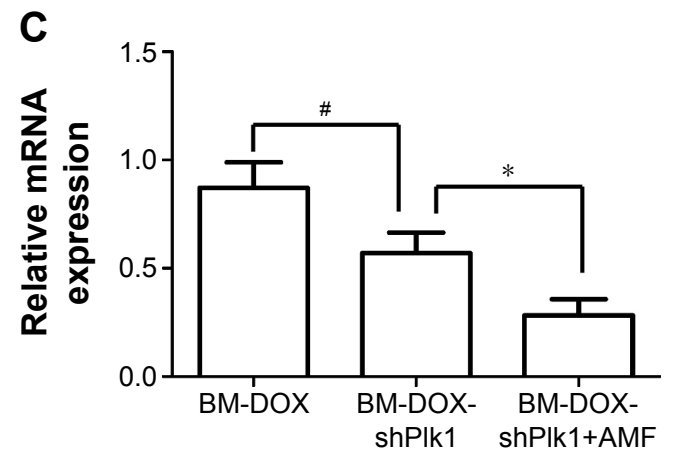

Figure 6 PlkI expression driven by the HSP70 promoter was significantly induced by hyperthermia.

Notes: (A) PlkI protein expression was detected by Western blot. Lane I, BM-DOX group; lane 2, BM-DOX-shPlkI group; lane 3, BM-DOX-shPlkI+AMF group. (B) Relative band intensity of PlkI of BM-DOX, BM-DOX-shPlkI, and BM-DOX-shPlkI+AMF groups compared to the intensity of GAPDH protein in each group. Each value is represented as mean $\pm S D(n=6)$. ${ }^{*} P<0.05$ compared with $B M-D O X$ group. ${ }^{*} P<0.05$ compared with $B M-D O X$-shPlkI group. (C) Relative amounts of PlkI mRNA expression of BM-DOX, BM-DOX-shPlkI, and BM-DOX-shPlkI+AMF groups compared to the amounts of $\beta$-actin mRNA in each group. Each value is represented as mean $\pm S D(n=6) .{ }^{*} P<0.05$ compared with BM-DOX group. $* P<0.05$ compared with BM-DOX-shPlkl group.

Abbreviations: AMF, alternating magnetic field; BM, bacterial magnetosome; DOX, doxorubicin; HSP70, heat shock protein 70; GAPDH, glyceraldehyde-3-phosphate dehydrogenase; PlkI, polo-like kinase I; shPIkI, recombinant eukaryotic plasmid pHSP70-PIkI-shRNA; SD, standard deviation. 


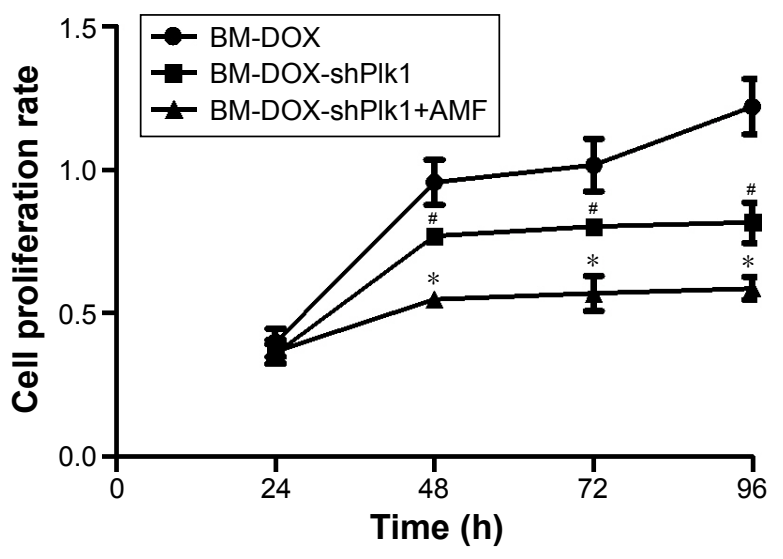

Figure 7 U2-OS cell proliferation rates after different treatments.

Notes: Each value is represented as mean $\pm S D(n=6)$. ${ }^{\#} P<0.05$ compared with BM-DOX group. $* P<0.05$ compared with BM-DOX-shPlkl group.

Abbreviations: AMF, alternating magnetic field; BM, bacterial magnetosome; DOX, doxorubicin; PlkI, polo-like kinase I; SD, standard deviation; shPlkI, recombinant eukaryotic plasmid pHSP70-PlkI-shRNA.

focused on the growth conditions. The concentration of the MTB cells primarily depends on the constituent of growth medium, such as iron source, nitrogen source, and carbon source. However, due to inadequate information about the culture of MTB, the production yield of BMs remains relatively low. Hence, before commercial application of BMs can be considered, optimized growth conditions for MTB need to be explored. In this study, the optimized growth conditions of MTB AMB-1 were investigated for enhancing both bacterial growth and production of BMs. The results showed that the optimal conditions of culture are an oxygen concentration of $4.0 \%$, a $\mathrm{pH}$ value of $7.0,20 \mu \mathrm{mol} / \mathrm{L}$ of ferrous sulfate, $800 \mathrm{mg} / \mathrm{L}$ of sodium nitrate, and $200 \mathrm{mg} / \mathrm{L}$ of succinic acid.

Gene therapy is a considerable approach for cancer treatment. Plk1, which belongs to the family of mitotic serine/threonine kinases, has been recognized as an important target for anticancer therapy. Recent preclinical studies concerning Plk1 in gene therapy always denied importance to effective delivery to tumor site or controlled amount of inhibitors. ${ }^{31}$ Indeed, control of therapeutic gene expression in tumors is essential for the study of gene therapy, because it can restrict cytotoxic gene expression to cancer cells. Various gene therapy research studies have focused on the establishment of regulable vectors which can be induced by physical stimuli, including ionizing radiation and hyperthermia. ${ }^{32-34}$ Among numerous inducible systems, the HSP promoter system combined with hyperthermia has been successfully employed in recent years. For this promoter system, the promoter region of human HSP70 was often used due to the very low basal expression in most cells. However, expression of genes under the control of HSP70 promoter can be upregulated by cellular stresses, such as heat stress..$^{35,36}$ Consequently, the combination of hyperthermia that is produced by BMs with HSP promoter system is an attractive strategy for tumor-targeted therapy.

In this study, a novel drug and gene co-delivery system was developed for tumor therapy. Using the system, both DOX and Plk1 shRNA can be specifically guided to tumor tissue by utilizing BMs as carriers under the effect of a magnetic field. In addition, BMs have been utilized as magnetic media for thermotherapy, and a HSP70 promoter has been used to strengthen the regulation and induction of Plk1 shRNA expression in a hyperthermia-triggered manner. In vitro experimental results revealed that this co-delivery system has potential application in combined chemotherapy, gene therapy, and thermotherapy for osteosarcoma. However, there are also some potential limitations of this study. The release of DOX from BMs in PBS is relatively high which
A

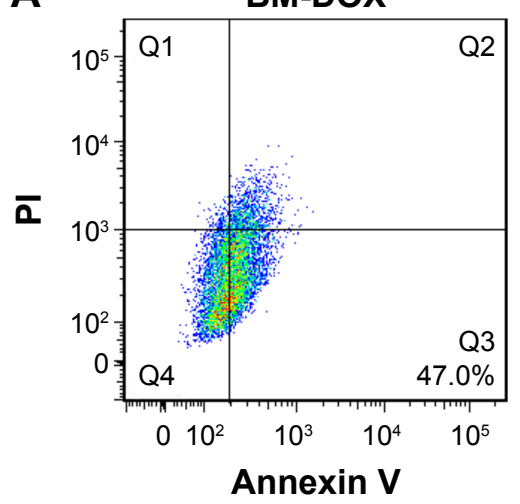

B

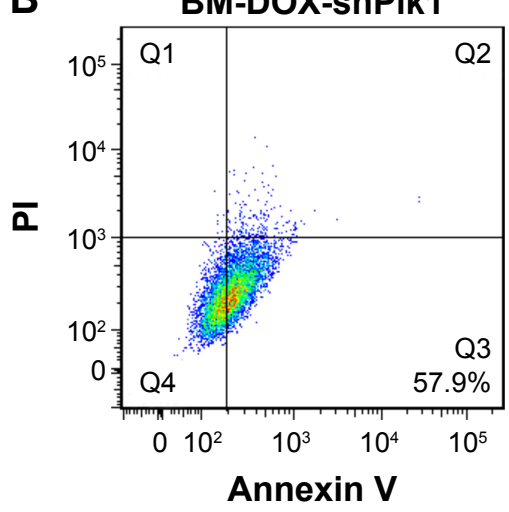

C

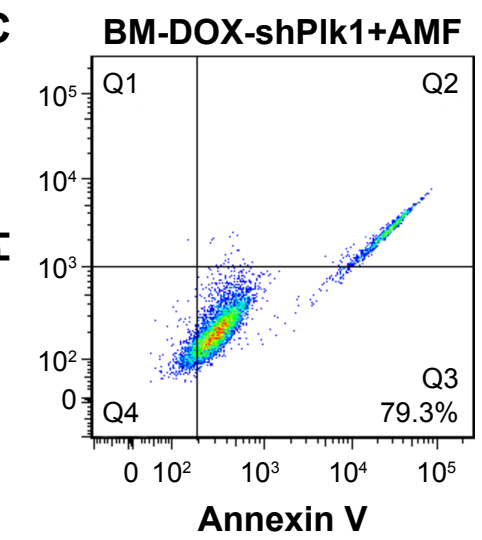

Figure 8 Apoptosis of U2-OS cells analyzed by flow cytometry after different treatments.

Notes: The apoptotic rate was $47.0 \%$ in the BM-DOX group (A), $57.9 \%$ in the BM-DOX-shPlkI group (B), and 79.3\% in the BM-DOX-shPlkI+AMF group (C).

Abbreviations: AMF, alternating magnetic field; BM, bacterial magnetosome; DOX, doxorubicin; PI, propidium iodide; PlkI, polo-like kinase I; shPlkI, recombinant eukaryotic plasmid pHSP70-PIkI-shRNA. 
showed that the binding of DOX with BMs is not stable and may cause problems during the final complex preparation for clinical application. Furthermore, the heat shock response may be activated by other factors, such as inflammation and fever. Further investigations are necessary for a comprehensive understanding of this co-delivery system. In vivo anticancer effects should also be evaluated in the future.

\section{Acknowledgments}

This work is supported by the National Natural Science Foundation of China (81441068) to Juehua Jing and the Foundation of Anhui Medical University (2015xkj034) to Li Cheng.

\section{Disclosure}

The author reports no conflicts of interest in this work.

\section{References}

1. Seow HF, Yip WK, Fifis T. Advances in targeted and immunobased therapies for colorectal cancer in the genomic era. Onco Targets Ther. 2016;9:1899-1920.

2. Melero I, Berman DM, Aznar MA, et al. Evolving synergistic combinations of targeted immunotherapies to combat cancer. Nat Rev Cancer. 2015;15(8):457-472.

3. Galluzzi L, Buque A, Kepp O, et al. Immunological effects of conventional chemotherapy and targeted anticancer agents. Cancer Cell. 2015;28(6):690-714.

4. Kumar CS, Mohammad F. Magnetic nanomaterials for hyperthermiabased therapy and controlled drug delivery. Adv Drug Deliv Rev. 2011; 63(9):789-808.

5. Kobayashi T, Kakimi K, Nakayama E, et al. Antitumor immunity by magnetic nanoparticle-mediated hyperthermia. Nanomedicine (Lond). 2014;9(11):1715-1726.

6. Hervault A, Thanh NT. Magnetic nanoparticle-based therapeutic agents for thermo-chemotherapy treatment of cancer. Nanoscale. 2014; 6(20):11553-11573.

7. Gobbo OL, Sjaastad K, Radomski MW, et al. Magnetic nanoparticles in cancer theranostics. Theranostics. 2015;5(11):1249-1263.

8. Alphandery E. Applications of magnetosomes synthesized by magnetotactic bacteria in medicine. Front Bioeng Biotechnol. 2014;2:5.

9. Alphandery E, Faure S, Seksek O, et al. Chains of magnetosomes extracted from AMB-1 magnetotactic bacteria for application in alternative magnetic field cancer therapy. ACS Nano. 2011;5(8):6279-6296.

10. Sun JB, Duan JH, Dai SL, et al. Preparation and anti-tumor efficiency evaluation of doxorubicin-loaded bacterial magnetosomes: magnetic nanoparticles as drug carriers isolated from Magnetospirillum gryphiswaldense. Biotechnol Bioeng. 2008;101(6):1313-1320.

11. Tang YS, Wang D, Zhou C, et al. Bacterial magnetic particles as a novel and efficient gene vaccine delivery system. Gene Ther. 2012;19(12): 1187-1195.

12. Liu YG, Dai QL, Wang SB, et al. Preparation and in vitro antitumor effects of cytosine arabinoside-loaded genipin-poly-l-glutamic acidmodified bacterial magnetosomes. Int J Nanomedicine. 2015;10: 1387-1397.

13. Alphandery E, Guyot F, Chebbi I. Preparation of chains of magnetosomes, isolated from Magnetospirillum magneticum strain AMB-1 magnetotactic bacteria, yielding efficient treatment of tumors using magnetic hyperthermia. Int J Pharm. 2012;434(1-2):444-452.

14. Yamaguchi M, Ito A, Ono A, et al. Heat-inducible gene expression system by applying alternating magnetic field to magnetic nanoparticles. ACS Synth Biol. 2014;3(5):273-279.
15. Yamaguchi M, Ito A, Okamoto N, et al. Heat-inducible transgene expression system incorporating a positive feedback loop of transcriptional amplification for hyperthermia-induced gene therapy. J Biosci Bioeng. 2012;114(4):460-465.

16. Ito $\mathrm{A}$, Okamoto $\mathrm{N}$, Yamaguchi $\mathrm{M}$, et al. Heat-inducible transgene expression with transcriptional amplification mediated by a transactivator. Int J Hyperthermia. 2012;28(8):788-798.

17. Qi J, Liu X, Liu J, et al. Molecular characterization of heat shock protein 70 (HSP 70) promoter in Japanese flounder (Paralichthys olivaceus), and the association of Pohsp70 SNPs with heat-resistant trait. Fish Shellfish Immunol. 2014;39(2):503-511.

18. Strebhardt K. Multifaceted polo-like kinases: drug targets and antitargets for cancer therapy. Nat Rev Drug Discov. 2010;9(8):643-660.

19. Lens SM, Voest EE, Medema RH. Shared and separate functions of polo-like kinases and aurora kinases in cancer. Nat Rev Cancer. 2010; 10(12):825-841.

20. Gjertsen BT, Schoffski P. Discovery and development of the Pololike kinase inhibitor volasertib in cancer therapy. Leukemia. 2015; 29(1):11-19.

21. Cheng L, Wang C, Jing J. Polo-like kinase 1 as a potential therapeutic target for osteosarcoma. Curr Pharm Des. 2015;21(10):1347-1350.

22. Isakoff MS, Bielack SS, Meltzer P, et al. Osteosarcoma: current treatment and a collaborative pathway to success. J Clin Oncol. 2015;33(27): 3029-3035.

23. Gill J, Ahluwalia MK, Geller D, et al. New targets and approaches in osteosarcoma. Pharmacol Ther. 2013;137(1):89-99.

24. Teagle AR, Birchall JC, Hargest R. Gene therapy for pyoderma gangrenosum: optimal transfection conditions and effect of drugs on gene delivery in the HaCaT cell line using cationic liposomes. Skin Pharmacol Physiol. 2016;29(3):119-129.

25. Makridis A, Chatzitheodorou I, Topouridou K, et al. A facile microwave synthetic route for ferrite nanoparticles with direct impact in magnetic particle hyperthermia. Mater Sci Eng C Mater Biol Appl. 2016;63: 663-670.

26. Lee $\mathrm{S}$, Ahn JH, Choi $\mathrm{H}$, et al. Natural magnetic nanoparticle containing droplet for smart drug delivery and heat treatment. Conf Proc IEEE Eng Med Biol Soc. 2015;2015:3541-3544.

27. Darwish MS, Nguyen NH, Sevcu A, et al. Dual-modality self-heating and antibacterial polymer-coated nanoparticles for magnetic hyperthermia. Mater Sci Eng C Mater Biol Appl. 2016;63:88-95.

28. Kornig A, Dong J, Bennet M, et al. Probing the mechanical properties of magnetosome chains in living magnetotactic bacteria. Nano Lett. 2014;14(8):4653-4659.

29. Mathuriya AS. Magnetotactic bacteria for cancer therapy. Biotechnol Lett. 2015;37(3):491-498.

30. Greene SE, Komeili A. Biogenesis and subcellular organization of the magnetosome organelles of magnetotactic bacteria. Curr Opin Cell Biol. 2012;24(4):490-495.

31. Garuti L, Roberti M, Bottegoni G. Polo-like kinases inhibitors. Curr Med Chem. 2012;19(23):3937-3948.

32. Tato-Costa J, Casimiro S, Pacheco T, et al. Therapy-induced cellular senescence induces epithelial-to-mesenchymal transition and increases invasiveness in rectal cancer. Clin Colorectal Cancer. 2016;15(2): $170-178$.

33. Son B, Jun SY, Seo H, et al. Inhibitory effect of traditional oriental medicine-derived monoamine oxidase B inhibitor on radioresistance of non-small cell lung cancer. Sci Rep. 2016;6:21986.

34. Fortin PY, Lepetit-Coiffe M, Genevois C, et al. Spatiotemporal control of gene expression in bone-marrow derived cells of the tumor microenvironment induced by MRI guided focused ultrasound. Oncotarget. 2015; 6(27):23417-23426.

35. Wang X, Zhou P, Sun X, et al. Modification of the hTERT promoter by heat shock elements enhances the efficiency and specificity of cancer targeted gene therapy. Int J Hyperthermia. 2016;32(3):244-253.

36. Noyan F, Diez IA, Hapke M, et al. Induced transgene expression for the treatment of solid tumors by hematopoietic stem cell-based gene therapy. Cancer Gene Ther. 2012;19(5):352-357. 


\section{Publish your work in this journal}

The International Journal of Nanomedicine is an international, peerreviewed journal focusing on the application of nanotechnology in diagnostics, therapeutics, and drug delivery systems throughout the biomedical field. This journal is indexed on PubMed Central, MedLine, CAS, SciSearch $\AA$, Current Contents $\AA /$ Clinical Medicine,

Journal Citation Reports/Science Edition, EMBase, Scopus and the Elsevier Bibliographic databases. The manuscript management system is completely online and includes a very quick and fair peer-review system, which is all easy to use. Visit http://www.dovepress.com/ testimonials.php to read real quotes from published authors.

Submit your manuscript here: http://www.dovepress.com/international-journal-of-nanomedicine-journal 